\title{
Contemporary Marxism and Post-industrial Economy
}

\author{
Victoria S. Gritsenko \\ Perm National Research Polytechnic University
}

\begin{abstract}
Karl Marx (1973) scientifically predicted the appearance of some extraordinary tendencies of social development in the second half of the 20th century was given a common name of post-industrial or informational society and interpreted as post-bourgeois, post-capitalist, post-business society, and late capitalism. Autonomist Marxism and Perm philosophy school had separately come to a conclusion that all the phenomena noticed by the post-industrial theory could be adequately explained if we consider the historically new form of material labour appearing now. Marx (1973), who predicted this new form, named it automated, scientific, or universal labour. With the appearance of the universal labour, the wealth of the society depends on the universal human powers that help to involve the extensive powers of nature into the production process. Universal labour can not be averaged or measured by the labour time as the abstract labour; it implies high complexity and creativity. Involving increasingly powerful forces of nature and human society, it appears to be the labour of another essence and by its essence, it does not create value.
\end{abstract}

Keywords: modern Marxism, universal labour, destruction of value, post-industrial society, information

\section{Karl Marx and Post-industrial Theories}

Karl Marx has created the scientific philosophy of dialectical and historical materialism. The materialist conception of history is based on the understanding of material labour as the fundament of social life and the process of history. The materialist conception of history was substantiated in "Capital." As is well-known, "Capital" was not finally finished, although the main economic idea of "Capital" that represents the materialist conception of history is formulated abundantly. The notion of labour is analyzed besides in "Grundrisse."

In his outstanding "Grundrisse" and in "Capital. Vol. 3," Karl Marx (1973; 1985) scientifically predicted the appearance of some extraordinary tendencies of social development in the second half of the 20th century was given a common name of post-industrial or informational society and interpreted as post-bourgeois, post-capitalist, post-business society, and late capitalism.

It is quite clear that post-industrial theories borrowed much from Marx, although they have politicized against Marxism. Hertzberg (1995) points out that Toffler's three waves are in fact Marx's main socio-economic formation.

According to Nick Dyer-Witheford (1999),

The relation of these theories to Marxism is, however, not just one of antagonism, but of appropriation. Produced by intellectuals who were often familiar with or had actually espoused Marxist ideas, the concept of the information society derives much of its analytic force and imaginative power from a rewriting of Marxism that retains the notion of historical

Victoria S. Gritsenko, Ph.D., lecturer, Perm National Research Polytechnic University, Russia; main research fields: Marxism, Post-industrial Society, and Philosophy of Economy, World System Theory. Email: gritsenkovs89@mail.ru. 
progress towards a classless society, but reinscribes technological advance rather than class conflict as the driving force in this transformation. (63)

The Head of the Perm State University school of the scientific philosophy Professor Vladimir Orlov appreciates the post-industrial society as late capitalism. He (2006) thinks about post-industrial, or informational, theory as about a "quite interesting version of the contemporary stage of the society development undergoes profound technical, economical and cultural changes. A number of sides of these changes were described by the theory of post-industrial society." But, he (2006) claims, if we want to analyze the essence of the changes, we need to appeal to the Marxist formation theory made up on the deep-seated understanding of the essence of man and society, the general naturally determined process of history, material labour and its role in the human progress. The most serious philosophical questions of the modern society - those of the essence of the main contemporary form of the material labour, of the universal means of production, and of the relation of the technical and personal components of the social reality — are raised mainly by the Marxists.

So, what makes modern Marxist theories studying contemporary society very unlike its post-industrialist analogues is their fundamental basis. Autonomist Marxism and Perm philosophy school had separately come to a conclusion that all the phenomena noticed by the post-industrial theory could be adequately explained if we consider the historically new form of material labour, appeared now. Marx, who predicted this new form, named it automated, scientific, or universal labour.

\section{Universal (Automated) Labour}

In "Capital. Vol. 3," Marx (1981) gives a sketch of it as of all the scientific work and all discoveries inventions. It is brought about partly by the co-operation of men now living, but partly also by building on earlier work. The fruits of this collective project are, Marx argues, generally appropriated by the "most worthless and wretched kind of money-capitalists." But the ultimate source of their profit is the "new developments of the universal labour of the human spirit and their social applications by combined labour."

In "Grundrisse," he develops the term of automated labour (the earliest form of the universal labour). Automated labour is the application of knowledge and experimental science, creative and materially embodied science. It indicates that a man turns from a direct participant of production process into its controller and regulator.

Marx (1981) predicts capital's drive to dominate living labour through machinery will mean that "the creation of real wealth comes to depend less on labour time and on the amount of labour employed" than on "the general state of science and on the progress of technology." Technological application of science, the opening of the universal essential forces of human being and the highest point of the development of matter, which is taking under the control more and more powerful forces of nature becomes the main production factors. The universal labour (which is sometimes called "scientific," in a broad sense) is closely connected with science as the universal historical product of human spirit, but does not coincide with it. Universal labour is the practical appliance of science, it is the labour highly saturated with science. If the historically previous forms of labour, such as hand-labour and machinery labour were based mostly on experience and practice, this new form appears on the fundament of sufficiently high level of science.

That is why it is rather difficult to detach the advanced science from its technological application in the complicated labour while regarding the philosophical aspects of the problem. It is crucially important to ascertain the new form of labour as the material one, as well as hand-labour and machinery labour, but much 
more complicated than those. Modern Marxists, such as Sean Sayers and V. V. Orlov, gave quite a detailed argumentation of the material character of the universal labour. First and foremost, the question is how to understand the term "material character." As Lenin stated, matter is what acts upon our sense-organs and produces sensation; matter is the objective reality given to us in sensation. We may conclude that matter is not a synonym to the touchable, corporeal, or physical matter. That is why the material labour is not just direct or physical labour. The material labour is carried out with the help of the material means of production and creates the material product.

Sayers suggests a bright concept of labour as "formative" activity. He shows how the post-industrial immaterial labour theme comes from the wrong "productivist" logic that regards work that creates a material product—industrial, craft, or artistic work — as the paradigm for all work.

Orlov (2006) considers it would be naive to think that science as the universal spiritual human force could be embodied in the process of production "just" by simple physical labour, without any universal material substance, corresponding its level-universal labour. In "Grundrisse," there is also the distinction between the universal labour and the universal intellect. Finally, all the power of the philosophic basis of K. Marx's political economy theory makes us think so.

The basis and the necessary condition for various types of the universal labour, the direct reason of integration and accumulation of labour on the world scale and the core of the universal labour is computer labour. Computer is the universal means of material production by Thomas O'Donnell. Internet in this case appears as the first world collective productive structure incompatible with the local structures of the past. That is why computer labour has deeply collective character incommensurable with the collective labour of the previous epochs by its essence. The collective character of production at the industrial stage of development described in "Capital" is related with the division of labour and exchange. On the contrary, computer integrates and accumulates people's labour all over the world and of all generations directly. The bright example of the collective computer labour is net services like "Zoho" that help to provide collective scientific research. The phenomenon of greed computing also corresponds this idea.

The other types of universal labour are the so called social or humanitarian services that Daniel Bell (1973) has characterized as essentially non-market—science, education, administration, public health, and so on. Today, as Marx brilliantly predicted and post-industrial theorists such as Bell and Castells repeated, science has turned into a direct productive force. However, science, according to Marx, being in capitalist society a part of capital, never seems to fit in the scheme of capitalist mode of production. He used the labour of reciters, artists, teachers, and physicians to illustrate his thought.

Bell (1973) emphasises that the level of scientific development and especially fundamental science plays the key role in the potential of state forming. That is why the developed countries are now so concerned with organization of all the necessary conditions for the rapid progress in science and education. These humanitarian services, as Bell shows, have non-market character and they form a non-market economy of welfare where there are no adequate mechanisms of valuation of social goods. The state property and economy regulation in fact play a very important role in the modern combined economies of the developed countries.

With the appearance of the universal labour, the wealth of the society depends on the universal human powers that help to involve the extensive powers of nature into the production process. Universal labour cannot be averaged or measured by the labour time as the abstract labour; it implies high complexity and creativity. Involving increasingly powerful forces of nature and human society, it appears to be the labour of another 
essence and by its essence it does not create value. That is why it is so difficult to calculate the value and price of its products, such as computer programs, scientific invention, or innovation. It is the question of how much the doctrine of relativity costs. Of course, the old capitalist logic does its best to oppress the new form of labour and squeeze it into the old framework of capitalist relations.

\section{Universal Labour and Destruction of the Commodity Value}

Emerging of the universal labour, dialectically denying the previous stage of abstract labour, means the destruction of the proportion, or conformity, between material and abstract wealth, between use value and value, and between concrete and abstract labour. In other words, there happens the destruction, or the degeneration, of the commodity value relation itself that had formed the basis of the commodity production in general and capitalist production in particular for so long. This outstanding tendency was firstly noted by Marx and now its vivid symptoms are the so called business at a speed of thought and the fact that the dollar derivates mass exceeds real commodity production mass nearly 10 times. It was appositely one of the factors of the last world economic crisis in 2008-2010. The use value and value appear divorced and independent.

One more complicated problem in this respect is the problem of property. In history, there is a clear logic: pre-historical primeval society — collective labour — collective ownership of the means of production; feudalism and capitalism — private labour — private ownership; post-industrial society—universal labour — the logic leads to collective ownership again. And first and foremost, property unit now should be the most important subject and product of labour-information.

As far as we are concerned, no philosopher or economist excepts Marxists states the necessity of the collective ownership of information. However the reality of social life demonstrates that computer labour itself bulldozes its way outwards private property. The property principle is now attacked by the network (peer-to-peer) technologies of files exchange which had been grown so popular that in 2006 in Sweden the political unity of copyright antagonists was created. It received a legal name of the "pirates' party" and since 2009 the party is in the Swedish parliament. Following Sweden the analogous parties appeared in several countries of Europe, North and South America. And if we look through some programmers' forums on the Internet, we find out a popular cry for the socialization of information, especially of sources.

We do live in an amazingly breathtaking epoch. We became involuntary eye-witnesses of the appearance of the historically new form of material labour - universal labour - that inevitably brings with it the destruction of abstract labour on whose base capitalism had grown, came into blossom and makes its way to the end, and the destruction of value on whose base the commodity production had existed. So, what is next?

\section{Works Cited}

Bell, Daniel. “The coming of Post-Industrial Society." <https://www.os3.nl/_media/2011-2012/daniel_bell_-_the_coming_of_ Post_ndustrial_society.pdf $>$.

Dyer-Witheford Nick. "Cyber-Marx: Cycles and Circuits of Struggle in High Technology Capitalism." < http://www.fims. uwo.ca/people/faculty/dyerwitheford/index.htm >.

Hertzberg Hendrik. "Marxism: The Sequel." The New Yorker 7 (13 Feb., 1995): 6-7.

Lenin Vladimir Ilyich. "Materialism and Empirio-Criticism." <http://www.marxists.org/archive/lenin/works/1908/mec/three1. htm\#v14pp72h-144>.

Marx Karl. Capital: A Critique of Political Economy. Vol. 3. New York: Vintage Books, 1981. 198-99. 
---. Grundrisse. Harmondsworth: Penguin, 1973. 690.

O’ Donnel Thomas. "Universal Computation and the Information Age." <http://www.personal.umich.edu>.

Orlov Vladimir Vyacheslavovitch and Vasilieva Tatiana Stepanovna. Philosophy of Economy. Perm: Perm State University, 2006. C. 202.

Sayers Sean. "The Concept of Labour: Marx and His Critics." Science and Society 71.4 (2007): 431-54 $<$ http://www.kent.ac.uk/secl/philosophy/articles/sayers/conceptoflabour.pdf $>$. 